\title{
İspenç Tavuğu ve Horozlarında Bazı Morfolojik Özellikler
}

\author{
Demir ÖZDEMIR \\ Akdeniz Üniversitesi, Ziraat Fakültesi, Tarımsal Biyoteknoloji Bölümü, 07058, Antalya \\ (ORCID: https://orcid.org/0000-0003-2160-6485)
}

(Alınış / Received: 31.07.2019, Kabul / Accepted: 27.11.2018, Online Yayınlanma / Published Online: 16.03.2019)

\section{Anahtar Kelimeler İspenç tavuğu, Minyatür tavuk, Morfolojik \\ Karakterizasyon, Yerli tavuk irkları}

Özet: $\mathrm{Bu}$ araştırma, uzun yıllardır ülkemiz şartlarına başarı ile uyum sağlamış İspenç genotipine ait horoz ve tavuklarda bazı morfolojik standartları belirlemek amaciyla yapılmıştır. Araştırmada İspenç genotipine ait 105 horoz ve 146 tavukta 27 farklı morfolojik parametre incelenmiş ve örneklemeler Ankara, İzmir ve Antalya illerinde yetiştirilen farklı yaş dönemlerindeki farklı İspenç popülasyonlarında yapılmıştır. Araştırma bulgularına göre İspenç genotipinde vücut deri rengi beyaz olarak saptanmış ve tüm hayvanlarda yanak ve sakal tüyleri gözlenmiştir. İspenç genotipinin her iki cinsiyetinde de ayak bileklerinde paça tüyleri saptanmış ve her ayakta 5 adet parmak oluşumu gözlenmiştir. İspenç horoz ve tavuklarında ortalama canlı ağırlık sırasıyla 0.733 ve $0.582 \mathrm{~kg}$, vücut uzunluğu 41.85 ve $35.59 \mathrm{~cm}$, açlk kanat uzunluğu 50.04 ve 54.46, sirt uzunluğu 11.58 ve $10.98 \mathrm{~cm}$, göğüs genişliği 61.42 ve $55.32 \mathrm{~mm}$ ve boyun uzunluğu 71.71 ve $69.17 \mathrm{~mm}$ olarak saptanmıştır. Horozlarda yaş dönemi ile birlikte kafatası uzunluğu $(\mathrm{P}<0.05)$, kafatası genişliği $(\mathrm{P}<0.05)$, ibik uzunluğu $(\mathrm{P}<0.001)$, ibik genişliği $(\mathrm{P}<0.001)$ ve oküler genişlik $(\mathrm{P}<0.05)$ değerleri önemli düzeyde artarken, tavuklarda yaş dönemi ile birlikte kafatası uzunluğu $(\mathrm{P}<0.05)$, ibik uzunluğu $(\mathrm{P}<0.001)$, ibik genişliği $(\mathrm{P}<0.001)$ ve oküler uzunluk $(\mathrm{P}<0.05)$ değerlerindeki artış önemli bulunmuştur. Sonuç olarak bu araştırma İspenç genotipi üzerinde yapılan ilk çalışma niteliğindedir. Araştırma bulgularının İspenç genotipinin yerli tavuk ırkı olarak tescil edilme sürecine katkı sağlayacağı düşünülmektedir.

\section{Some Morphological Characteristics of İspenç Roosters and Chickens}

Keywords

İspenç fowl,

Miniature chicken,

Morphological

characterization,

Native chicken breeds

\begin{abstract}
This research was carried out to determine some morphological standards of İspenç roosters and chickens that have successfully adapted to the conditions of Turkey for many years. In the study, 27 different morphological parameters were investigated on 105 roosters and 146 chickens of İspenç genotype and the birds were sampled from different populations of different age groups that are grown in Ankara, İzmir and Antalya provinces. According to the research findings, the skin colour was white in the İspenç genotype and muff and beard feathers were observed in all animals. Both genders of the İspenç genotype were feather legged and 5 toes were observed in each foot. The average body was 0.733 and $0.582 \mathrm{~kg}$, body length was 41.85 and $35.59 \mathrm{~cm}$, open wingspan was 50.04 and 54.49 , back length was 11.58 and $10.98 \mathrm{~cm}$, chest width was 61.42 and 55.32 $\mathrm{mm}$ and neck length was 71.71 and $69.17 \mathrm{~mm}$ in roosters and chickens, respectively. With increasing age, there was a significant increase in skull length $(\mathrm{p}<0.05)$, skull width $(\mathrm{p}<0.05)$, comb length $(\mathrm{p}<0.001)$, comb width $(\mathrm{p}<0.001)$ and ocular width $(\mathrm{p}<0.05)$ in roosters, and skull length $(p<0.05)$, comb length $(p<0.001)$, comb width $(p<0.001)$ and ocular length $(\mathrm{P}<0.05)$ in chickens. It is thought that the results of this first research on the İspenç genotype will provide an important contribution to the İspenç genotype, which has the potential to be registered as a native chicken breed.
\end{abstract}

\section{Giriş}

Hayvansal üretim her geçen gün artan insan popülasyonunun ihtiyaçlarının karşılanmasında oldukça önemli bir paya sahip olmaktadır İhtiyaçlara bağlı talep artışı sanayi ve teknolojinin de gelişimi ile entansif hayvancılık uygulamalarında yüksek verime sahip az sayıdaki kültür ve sentetik rrklar üzerine yoğunlaşılmasına sebebiyet vermiştir. $\mathrm{Bu}$ yönelim yerli (lokal) ırkların üretimde daha az tercih 
edilmesine ve dolayısıyla giderek yok olmalarına neden olmaktadır. Birleşmiş Milletler Gıda ve Tarım Organizasyonu'nun (FAO) 2015 yılında yayınladığı gıda ve tarımda kullanılan hayvan genetik kaynaklarını konu alan raporunda dünya çiftlik hayvanları genetik kaynaklarının \% 17'sinin yok olma tehlikesiyle karşı karşıya olduğu, bu kaynakların \% 58'inin risk durumuyla ilgili ise hiçbir kayıt bulunmadı̆̆ı belirtilmiştir [1]. Aynı raporda 2000 ve 2014 yılları arasında 100 adet çiftlik hayvanı ırkının yok olduğu ve en fazla genetik kaybın kanatlı türlerinde yaşandığı belirtilmiştir [1].

Ticari tavukçuluğun başlamasından bu yana tavuk genetik çeşitliliği, yüksek verimli hatlara olan ilgi nedeniyle büyük bir kayba uğramış ve bunun sonucunda düşük ticari verime sahip birçok yerel tavuk ırkı yok olma tehlikesiyle karşı karşıya kalmıştır [2, 3, 4]. Tüm dünyada olduğu gibi ülkemizde de hayvansal üretimde en hızlı gelişme tavukçuluk sektöründe sağlanmış, ihtiyaç duyulan yumurta ve piliç eti üretimi tamamen yüksek verimli, yabancı orijinli hibritler üzerine odaklanmıștır; düşük verimli yerel tavuk urkları üretim prosesinde tercih edilmemiştir. Günümüzde Türkiye'deki mevcut tavuk Irkları, envanteri ve risk durumları hakkındaki bilgiler oldukça sinırlı kalmıştır. Mevcut tavuk ırklarının atası olarak kabul edilen Kırmızı Orman Tavuğu'nun M.Ö. 2000'li yıllarda Çin ve Hindistan bölgesinde ilk evcilleştirilmelerinden bu yana Asya ve Avrupa arasında bir köprü görevi gören ve birçok medeniyete ev sahipliği yapmış Anadolu'da çeşitli yerel tavuk ırklarının varlığına rağmen, bugün sadece Denizli ve Gerze tavuk irklarının resmi olarak tanınıyor olması bu konuda yapılan çalışmaların yetersizliğini göz önüne sermektedir.

Son zamanlarda gen kaynaklarının korunmasına yönelik tüm dünyada bilimsel, ekonomik, yasal ve sosyal gelişmeler hız kazanırken, uzun yıllardır ülkemizde bulunan yerel tavuk genotiplerimizle ilgili ne yazık ki yeterli düzeyde bilgi sağlanamamıștır [5]. Yerli tavuk ırkı tanımlamalarına katkıda bulunmak amacıyla planlanan bu araştırmada, geçmişten günümüze ülkemizin çeşitli bölgelerine uyum sağlamış ve verimli bir biçimde yetiștiriciliği yapılan Íspenç tavuğu ve İspenç horozu incelenmiştir. Bu genotipe dair herhangi bir bilimsel araştırmanın bulunmaması nedeniyle araştırma bulgularının hem gen kaynaklarının korunmasına hem de alan yazına bir katkı sağlayacağı düşünülmektedir.

Küçük vücut yapısı itibariyle minyatür bir tavuk ırkı olan ve Türkiye'de uzun yıllardır hobi ve süs tavuğu yetiştiricileri tarafından ilgi ile yetiștirilen İspenç genotipi, halk arasında hareketli, agresif tavırları sebebiyle "cin" ve ayak bileğini tamamen örten tüyleri nedeniyle "paçalı" gibi isimlerle de tarif edilmektedir. Irkı yetiştiren ilgili yetiștiricilerin internet üzerinden katıldığı tartışma platformlarında [6] İspenç tavuğunun Osmanlı İmparatorluğu döneminde çoğunlukla gayri Müslümler tarafından yetiştirildiği ileri sürülmektedir. Nitekim "İspenç" isminin Osmanlı İmparatorluğu döneminde gayri Müslümlerden alınan bir çeşit tarım vergisi anlamına gelen "İspenç" kelimesinden türediğine dair bilgiler de literatürde yer almaktadır [7]. Denizli ve Gerze tavuk ırklarında olduğu gibi İspenç genotipinin ülkemizdeki geçmişi hakkında da somut bir bilgi bulunmamasına rağmen Mersin'in Mut ilçesi yakınlarında yer alan ve M.S. 5. Yüzyıla ait Dağ Pazarı Kilisesinin taban mozaiklerinde İspenç tavuğu figürlerine rastlanmıştır [8]. Kendine has özellikleriyle uzun yıllardır ülkemizin çeşitli bölgelerinde yetiştirilen İspenç genotipi, küçük vücut yapısı ve farklı renk varyetelerinin yanı sıra düşük yem tüketimi (60-65 g/gün) ve yumurta verimiyle (160-180 adet/yıl) de hobi tavukçuluğu yapan yetiştiriciler tarafından tercih edilen bir kümes hayvanı olarak dikkat çekmektedir (yetiştirici koşullarında elde edilen verilerdir). Avrupa KanatlıGüvercin-Kafes Kuşu-Tavşan ve Kobay Yetiştiricileri Birliği (EE) tarafından 2016 yılında yayınlanan minyatür tavuk ırkı standartları raporunda dünya genelinde 151 adet minyatür tavuk ırkı tanımlanmıştır [9]. Tanımlanan minyatür tavuk ırkları arasında henüz yer almayan İspenç genotipi Hollanda ve Belçika'da yetiştirilen minyatür tavuk rrklarıyla fenotipik olarak benzerlik gösterse de sahip olduğu ibik yapısı, parmak sayısı, vücut duruşu, kılıç ve paça tüyleri gibi spesifik karakterler bakımından Avrupa'daki benzerlerinden farklılık göstermektedir.

Son yıllarda çiftlik hayvanları genetik kaynaklarının biyoçeşitliliğinde yaşanan kayıplar dikkat çekici hale gelmiş ve mevcut hayvan ırklarının tanımlanmasına yönelik araştırmalara olan yönelim artmıştır. Çiftlik hayvanları genetik kaynaklarının tanımlanmasında son zamanlarda genomik karakterizasyon yöntemleri geliştirilmiş olsa da hayvan genetik kaynaklarının çeşitliliğinin etkili bir şekilde değerlendirilmesinde fenotipik karakterizasyon ön koşul olarak gösterilmekte ve hayvan irklarının tanımlanmalarında genomik bilginin mutlaka fenotipik ve morfolojik tanımlamalarla desteklenmesi gerektiği bildirilmektedir [10]. Bu kapsamda, araştırmanın amacı uzun yıllardır ülkemiz şartlarına başarı ile uyum sağlamış, yerli tavuk ırkı olarak tescil edilme potansiyeli olan İspenç genotipine ait tavuk ve horozlarda bazı morfolojik standartları belirlemek ve rrkın tescili için gerekli fenotipik ve morfolojik verileri sağlamaktır.

\section{Materyal ve Metot}

Araştırmanın hayvan materyalini İspenç genotipine ait çeşitli yaş dönemlerindeki 146 tavuk ve 105 horoz oluşturmuştur. Örnekleme yapılan hayvanlar Ankara (Polatlı), İzmir (Urla, Menderes, Karabağlar, Buca), Antalya (Konyaaltı, Kepez, Muratpaşa) illerindeki Türkiye Süs Tavukları ve Bahçe Hayvanları Federasyonu'na bağlı İspenç Kulübü üyesi yetiştirici 
kümeslerinden sağlanmıștır. Hayvanların yaşlarına ait veriler yetiştiriciler tarafından tutulan kayıtlardan sağlanmıştır. İspenç tavuk ve horozlarına ait bazı fenotipik özelliklerin belirlenmesinde FAO [10] tarafından tavuklar için önerilen fenotipik ölçüm yöntemleri ve Francesch vd.'nin [11] belirttiği zoometrik ölçüm yöntemleri kullanılmıştır. Tavuk ve horozlara ait çift uzuvların ölçümünde hayvanın sadece sağ tarafından örnekleme yapılmıştır. Ölçümler sırasında bir kişi hayvanı ölçüm pozisyonunda tutmuş diğer kişi ölçüm yapmıştır. Kişiye bağlı ölçüm hatalarını minimize edebilmek için tüm ölçümler yazar tarafından yapılmıştır.

Bireysel olarak örneklenen tavuk ve horozlarda 3 kategoride toplam 27 morfolojik parametre incelenmiştir.

\subsection{Genel vücut ölçümleri}

Canlı ağırlık, vücut uzunluğu, açık kanat uzunluğu, sırt uzunluğu, göğüs genişliği ve boyun uzunluğu olmak üzere 6 morfometrik parametre saptanmıștır.

Canlı ağırlık: Tartımlar bireysel olarak $0.01 \mathrm{~g}$ hassasiyetteki portatif dijital terazi ile yapılmıştır.

Vücut uzunluğu: Ölçüm yapılacak tavuk veya horoz, üzerinde şerit metre bulunan ölçüm düzlemine sirt üstü yatırılmış; gaga ucu ile kuyruğun son uç noktası arasındaki mesafe ölçülmüştür.

Açık kanat uzunluğu: Sirt üstü ölçüm düzlemine yatırılan hayvanların kanatları açılarak her iki kanatın en uzun primer tüyleri arasındaki mesafe şerit metre ile ölçülmüştür.

Sirt uzunluğu: Son boyun omurunun vücut ile birleştiği nokta ile pigostil arasındaki mesafenin 0.01 mm hassasiyetteki dijital kumpas ile ölçümüyle saptanmıştır.

Göğüs genişliği: Ölçüm düzlemine yatırılan tavuk ve horozların gögüs genişlikleri $0.01 \mathrm{~mm}$ hassasiyetteki dijital kumpas ile ölçülmüştür.

Boyun uzunluğu: Ölçüm yapılacak tavuk veya horoz sol tarafı üzerine ölçüm düzlemine yatırılarak boyun omurlarının vücutla birleştiği nokta ile ense kökü arasındaki mesafe $0.01 \mathrm{~mm}$ hassasiyetteki dijital kumpas ile ölçülmüştür.

\subsection{Baş Ölçümleri}

İbik uzunluğu, ibik genişliği, oküler uzunluk, oküler genişlik, gaga uzunluğu, gaga genişliği, kulak lobu uzunluğu, kulak lobu genişliği, sakal uzunluğu ve sakal geniş̧liğine ait ölçümler Şekil 1'de gösterildiği üzere $0.01 \mathrm{~mm}$ hassasiyette dijital kumpas kullanılarak yapılmıştır.
Kafatası Uzunluğu: Gaganın kafatası birleșimi ile oksipital kemik arasındaki mesafenin $0.01 \mathrm{~mm}$ hassasiyetteki dijital kumpas ile ölçümüyle saptanmıştır (Şekil 1).

Kafatası genişliği: Göz hizasından kafatası kemiğinin genişliği $0.01 \mathrm{~mm}$ dijital kumpas ile ölçülmüştür (Şekil 1).

\section{3. İncik ve ayak ölçümleri}

İncik ve ayaklar üzerinde yapılacak incelemelerde parmak sayısı, orta parmak uzunluğu, incik uzunluğu ve incik çapı olmak üzere 4 morfolojik ölçüm yapılmıştır. Her bireyde ayak parmak sayıları kaydedilerek orta parmak uzunluğu, incik uzunluğu ve incik çapı $0.01 \mathrm{~mm}$ hassasiyetteki dijital kumpas ile ölçülmüştür.

Morfolojik ölçümler dışında ırka ait göz rengi, vücut tüy rengi, deri rengi, kulak lobu rengi, ayak deri rengi ve ibik şekli gibi kalitatif fenotipik özellikler de bireysel olarak kaydedilmiştir.

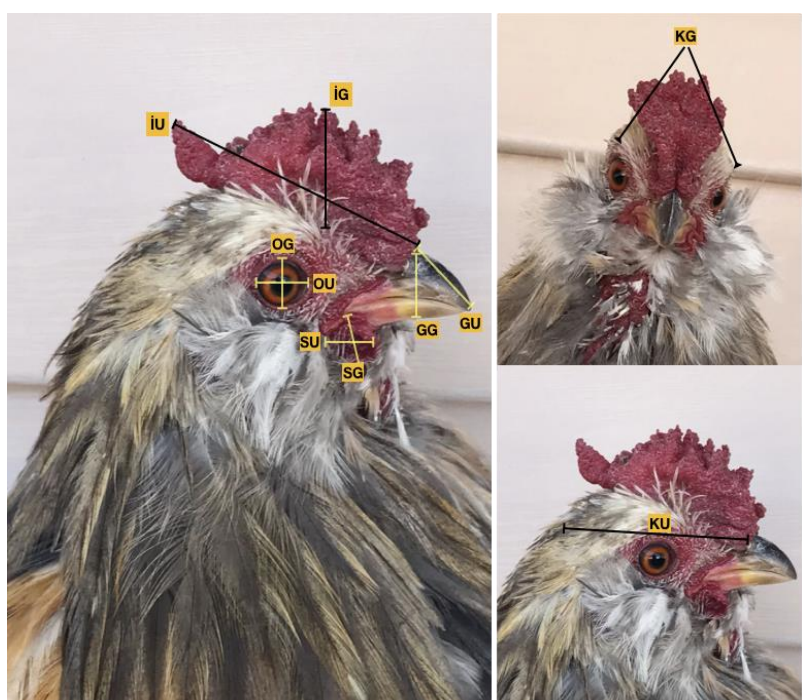

Şekil 1. İspenç horozunda baş bölgesi morfolojik ölçüm yerleri. İU: İbik uzunluğu, İG: İbik genişliği, GU: Gaga uzunluğu, GG: Gaga genișliği, OU: Oküler uzunluk, OG: Oküler genişlik, KU: Kafatası uzunluğu, KG: Kafatası genişliği.

\section{4. İstatistik Analiz}

Örnekleme yapılan hayvanlara ait kalitatif fenotipik özelliklerin cinsiyete bağlı frekans dağılımları SPSS 22.0 istatistik paket programı kullanılarak hesaplamıştır [12]. İncelenen bireylerin kantitatif morfolojik özelliklerinin (canlı ağırlı ve vücut ölçümleri) cinsiyet ve yaşa bağlı olarak değişimi SPSS 23.0 istatistik paket programının Genel Doğrusal Model prosedürüne göre analiz edilmiş, gruplara ait ortalamaların karşılaştırılmasında Duncan çoklu karşılaştırma testi uygulanmıştır [12]. 


\section{Bulgular ve Tartışma}

Örnekleme yapılan toplam 251 adet İspenç genotipli hayvanda her iki cinsiyette ibik şekli gül ibik olarak saptanmıştır. İncelenen tüm hayvanlarda vücut deri rengi beyaz olarak saptanmış, her iki cinsiyette de yanak ve sakal tüyleri görülmüştür. İspenç genotipinde diğer tavuk irklarından farklı olarak her iki cinsiyette beş adet parmak bulunduğu ve ayak bileklerinin tamamen tüylerle kaplı olduğu saptanmıştır. Farklı renk varyetelerine sahip olması nedeniyle süs tavuğu yetiştiricilerinin beğenisini kazanan İspenç genotipine ait gözlenen vücut tüy renkleri ve tüy renklerinin frekansları Tablo 1 ve Şekil 2'de verilmiştir. Araştırma bulgularına göre İspenç genotipinde horozlarda (\%14.3) ve tavuklarda (23.3) en fazla görülen tüy rengi, temel sarı vücut tüyleri üzerine beyaz noktaların oluşturduğu sarı karyağdı desenidir. Horozlarda altın keklik deseni (gold patridge) \% 10.5 ve kırmızı tüy rengi \% 4.8 olarak gözlenirken bu renk desenleri tavuklarda görülmemiştir (Tablo 1). İspenç genotipinde her iki cinsiyette de vücut tüy renklerinin ağırlıklı olarak sarı ve altın tonlarında olduğu saptanmıștır.

Tablo 1. İspenç genotipine ait horoz ve tavuklarda gözlenen vücut tüy rengi frekansları.

\begin{tabular}{llcc}
\hline Vücut Tüy Rengi & $\begin{array}{c}\text { Uluslararası } \\
\text { Renk Tanımı }\end{array}$ & $\begin{array}{c}\text { Horoz } \\
\%\end{array}$ & $\begin{array}{c}\text { Tavuk } \\
\%\end{array}$ \\
\hline Sarı Karyağdı & Buff Mottled & 14.3 & 23.3 \\
Mavi & Blue & 8.6 & 11 \\
Altın Karyağdı & Gold Mottled & 7.6 & 1.4 \\
Siyah Karyağdı & Black Mottled & 8.6 & 6.8 \\
Altın & Gold & 7.6 & 6.8 \\
Altın Keklik Deseni & Gold Patridge & 10.5 & - \\
Beyaz & White & 9.5 & 6.8 \\
Sarı & Buff & 7.6 & 16.4 \\
Kahverengi Karyağdı & Brown Mottled & 6.7 & 17.8 \\
İzabel & Isabel & 7.6 & 4.1 \\
Kırmızı & Red & 4.8 & - \\
Lekeli & Splash & 6.7 & 5.5 \\
& & 105 & 146 \\
\hline
\end{tabular}

İspenç genotipine ait horoz ve tavuklarda gözlenen göz rengi, kulak lobu rengi ve ayak deri rengi özelliklerine ait frekanslar Tablo 2'de verilmiștir.

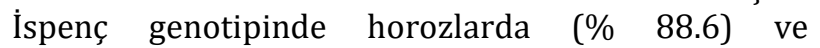
tavuklarda (\% 82.2) yaygın olarak rastlanan göz rengi turuncu olarak tespit edilmiştir. Kulak lobu rengi tavuklarda ağırlıklı olarak beyaz (\% 53.4) ve beyaz üzeri mavi (\% 42.5) olarak değişim gösterirken horozlarda en sık rastlanan kulak lobu rengi kırmızı (\% 79) olarak saptanmıştır (Tablo 2). İspenç genotipinde ayak deri rengi beyaz, gri, yeşil ve sarı olmak üzere dört grupta toplanmıştır. Tavuklarda en yaygın ayak deri rengi gri ( $\% 55.5)$ ve beyaz (\% 26.7) olarak saptanırken horozlarda görülen ayak deri rengi sırasıyla beyaz ( $\% 34.3)$, gri $(22.9)$, yeşil $(\%$ 21.9) ve sarı (\% 21) olarak belirlenmiştir (Tablo 2). Farklı yaş dönemlerindeki İspenç tavuk ve horozlarının genel vücut ölçümlerine ait ortalamalar
Tablo 3'te verilmiştir. İspenç horoz ve tavuklarında ortalama canlı ağırlıklar sırasıyla $0.733 \mathrm{~kg}$ ve 0.582 kg olarak saptanmıştır.

Tablo 2. İspenç genotipine ait horoz ve tavuklarda gözlenen göz rengi, kulak lobu rengi ve ayak deri rengi frekansları.

\begin{tabular}{lcc}
\hline Göz Rengi & Horoz $\%$ & Tavuk $\%$ \\
\hline Kahve Rengi & 11.4 & 12.3 \\
Turuncu & 88.6 & 82.2 \\
Sarı Tonları & - & 5.5 \\
& & \\
Kulak Lobu Rengi & & \\
Kırmızı & 79 & 4.1 \\
Beyaz & 15.2 & 53.4 \\
Beyaz Üzeri Mavi & 5.7 & 42.5 \\
& & \\
Ayak Deri Rengi & & \\
Beyaz & 34.3 & 26.7 \\
Gri & 22.9 & 55.5 \\
Yeșil & 21.9 & 11.6 \\
Sarı & 21 & 6.2 \\
\hline $\mathrm{N}$ & 105 & 146 \\
\hline
\end{tabular}

Horozlarda canlı ağırlık, vücut uzunluğu, kanat uzunluğu, sırt uzunluğu ve göğüs genişliği ortalamalarında ilerleyen yaş dönemi ile birlikte artış gözlenmiş ve bu özelliklerin ortalamalarının yaş dönemlerine göre değişimi önemli bulunmuştur $(\mathrm{P}<0.001)$. Tavuklarda canlı ağırlık $(\mathrm{P}<0.001)$, sirt uzunluğu $(\mathrm{P}<0.05)$ ve göğüs genişliği $(\mathrm{P}<0.001)$ özelliklerine ait ortalamaların yaş dönemlerine göre değişimi önemli bulunmuştur (Tablo 3).

Farklı yaş dönemlerindeki İspenç horoz ve tavuklarının baş bölgesi morfolojik ölçüm ortalamaları Tablo 4'te verilmiştir. Horozlarda yaş dönemi ile birlikte kafatası uzunluğu $(\mathrm{P}<0.05)$, kafatası genişliği $(\mathrm{P}<0.05)$, ibik uzunluğu $(\mathrm{P}<0.001)$, ibik genişliği $(\mathrm{P}<0.001)$ ve oküler genişlik $(\mathrm{P}<0.05)$ değerleri önemli düzeyde artarken, tavuklarda yaş dönemi ile birlikte kafatası uzunluğu $(\mathrm{P}<0.05)$, ibik uzunluğu $(\mathrm{P}<0.001)$, ibik genişliği $(\mathrm{P}<0.001)$ ve oküler uzunluk $(\mathrm{P}<0.05)$ değerlerindeki artış önemli bulunmuştur (Tablo 4). İlerleyen yaș ile birlikte horozlarda gaga uzunluğu $(\mathrm{P}<0.05)$ ve gaga genişliği $(\mathrm{P}<0.001)$ özelliklerindeki artış önemli bulunurken tavuklarda gaga uzunluğu ve genişliğinde yaş ile birlikte önemli bir değişiklik saptanmamıştır. Horozlarda, kulak lobu uzunluğu $(\mathrm{P}<0.05)$, sakal uzunluğu $(\mathrm{P}<0.05)$ ve sakal genişliği $(\mathrm{P}<0.01)$; tavuklarda ise kulak lobu uzunluğu $(\mathrm{P}<0.05)$, sakal uzunluğu $(\mathrm{P}<0.01)$ ve sakal genişliği $(\mathrm{P}<0.05)$ özeliklerinin yaş dönemlerine göre değișimi önemli bulunmuştur (Tablo 4). İspenç horoz ve tavuklarının ayak ve bacak bölgesi morfolojik ölçümleri Tablo 5'te verilmiştir. İspenç horoz ve tavuklarında incik uzunluğu değerlerinin yaş dönemine göre değişimi önemli bulunmazken, tavuklarda orta parmak uzunluğu $(\mathrm{P}<0.05)$ ve horozlarda incik çapı $(\mathrm{P}<0.01)$ değerlerinin yaş dönemlerine göre değişimi önemli bulunmuştur. 


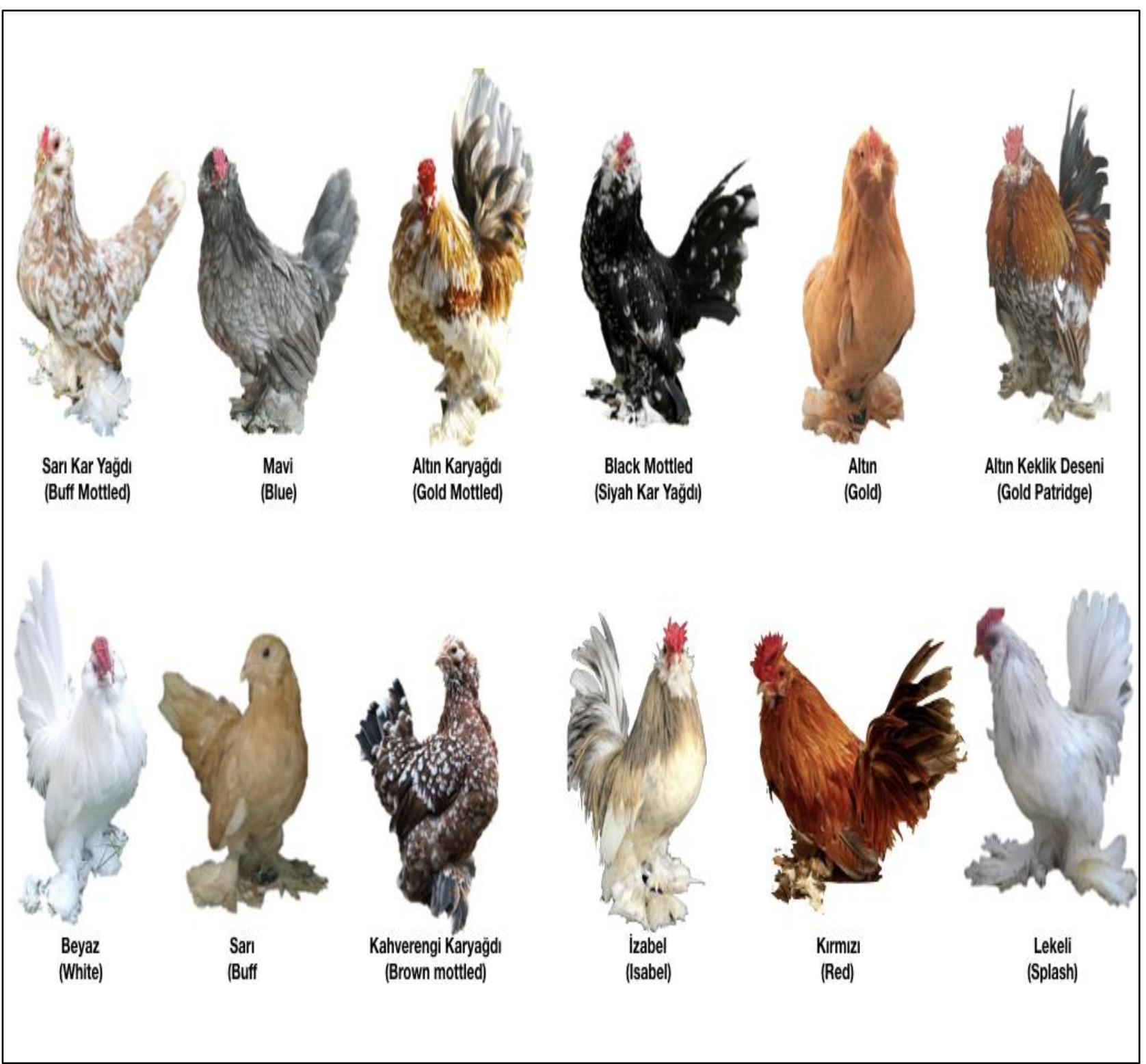

Şekil 2. İspenç genotipli tavuk ve horozlarda görülen vücut tüy renkleri. Renklerin uluslararası müsabakalarda kullanılan tanımlamaları parantez içerisinde belirtilmiştir. Şekil araştırmacı tarafından ölçüm yapılan hayvanlar kullanılarak oluşturulmuştur.

Tablo 3. İspenç horoz ve tavuklarının farklı yaș dönemlerine ait genel vücut ölçümleri

\begin{tabular}{|c|c|c|c|c|c|c|c|}
\hline $\begin{array}{l}\text { Yaş Dönemi } \\
\text { (hafta) }\end{array}$ & $\mathrm{N}$ & $\begin{array}{l}\text { Canlı Ağırlık } \\
\text { (kg) }\end{array}$ & $\begin{array}{l}\text { Vücut } \\
\text { Uzunluğu } \\
\text { (cm) }\end{array}$ & $\begin{array}{l}\text { Açık Kanat } \\
\text { Uzunluğu } \\
\text { (cm) }\end{array}$ & $\begin{array}{l}\text { Sirt Uzunluğu } \\
(\mathrm{cm})\end{array}$ & $\begin{array}{l}\text { Göğüs } \\
\text { Genişliği } \\
\text { (mm) }\end{array}$ & $\begin{array}{l}\text { Boyun Uzunluğu } \\
(\mathrm{mm})\end{array}$ \\
\hline Horoz & & $* * *$ & $* * *$ & *** & $* * *$ & $* * *$ & - \\
\hline $20-52$ & 35 & $0.659 \pm 0.01^{\mathrm{a}}$ & $39.21 \pm 0.31^{\mathrm{a}}$ & $58.46 \pm 0.26^{\mathrm{a}}$ & $10.86 \pm 0.07 \mathrm{a}$ & $58.61 \pm 0.46^{a}$ & $72.31 \pm 0.43$ \\
\hline $52-104$ & 40 & $0.754 \pm 0.01^{b}$ & $42.94 \pm 0.34^{b}$ & $58.67 \pm 0.28^{a}$ & $11.84 \pm 0.06^{b}$ & $61.55 \pm 0.49 b$ & $71.60 \pm 0.40$ \\
\hline $104+$ & 30 & $0.785 \pm 0.01^{c}$ & $43.40 \pm 0.32^{b}$ & $60.00 \pm 0.27 b$ & $12.03 \pm 0.07 c$ & $64.09 \pm 0.43^{c}$ & $71.24 \pm 0.46$ \\
\hline Ortalama & & $0.733 \pm 0.01$ & $41.85 \pm 0.19$ & $50.04 \pm 0.16$ & $11.58 \pm 0.04$ & $61.42 \pm 0.27$ & $71.72 \pm 0.25$ \\
\hline Tavuk & & $* * *$ & - & - & $*$ & $* * *$ & - \\
\hline $20-52$ & 66 & $0.537 \pm 0.01^{\mathrm{a}}$ & $36.25 \pm 0.30$ & $54.82 \pm 0.25$ & $10.80 \pm 0.08^{\mathrm{a}}$ & $52.48 \pm 0.42^{\mathrm{a}}$ & $69.60 \pm 0.60$ \\
\hline $52-104$ & 40 & $0.585 \pm 0.01^{b}$ & $36.67 \pm 0.38$ & $54.60 \pm 0.32$ & $11.04 \pm 0.10^{\mathrm{ab}}$ & $56.58 \pm 0.51^{b}$ & $68.29 \pm 0.73$ \\
\hline $104+$ & 40 & $0.624 \pm 0.01^{c}$ & $36.85 \pm 0.38$ & $53.97 \pm 0.32$ & $11.10 \pm 0.10^{\mathrm{b}}$ & $56.89 \pm 0.51^{b}$ & $69.23 \pm 0.73$ \\
\hline Ortalama & & $0.582 \pm 0.01$ & $36.59 \pm 0.20$ & $54.46 \pm 0.17$ & $10.98 \pm 0.05$ & $55.32 \pm 0.29$ & $69.17 \pm 0.39$ \\
\hline
\end{tabular}

***: P<0.001; *: P<0.05; -: P>0.05. Her bir cinsiyet için aynı sütunda farklı harfler taşıyan ortalamalar arasındaki fark önemli bulunmuștur. - : Önemsiz 
D. Özdemir/ İspenç Tavuğu ve Horozlarında Bazı Morfolojik Özellikler

Tablo 4. İspenç horoz ve tavuklarının baș bölgesi morfolojik ölçümleri.

\begin{tabular}{|c|c|c|c|c|c|c|c|}
\hline $\begin{array}{c}\text { Yaş } \\
\text { Dönemi } \\
\text { (hafta) }\end{array}$ & $\mathrm{N}$ & $\begin{array}{l}\text { Kafatası } \\
\text { Uzunluğu } \\
(\mathrm{mm})\end{array}$ & $\begin{array}{l}\text { Kafatası } \\
\text { Genişliği } \\
(\mathrm{mm})\end{array}$ & $\begin{array}{c}\text { İbik } \\
\text { Uzunluğu } \\
\text { (mm) }\end{array}$ & $\begin{array}{l}\text { İbik } \\
\text { Genişliği } \\
(\mathrm{mm})\end{array}$ & $\begin{array}{l}\text { Oküler } \\
\text { Uzunluk } \\
(\mathrm{mm})\end{array}$ & $\begin{array}{l}\text { Oküler Genişlik } \\
\text { (mm) }\end{array}$ \\
\hline Horoz & & $*$ & $*$ & $* * *$ & $* * *$ & - & * \\
\hline $20-52$ & 35 & $41.32 \pm 0.34^{\mathrm{a}}$ & $23.57 \pm 0.16^{a}$ & $38.83 \pm 0.68^{a}$ & $17.09 \pm 0.35^{\mathrm{a}}$ & $10.43 \pm 0.17$ & $7.07 \pm 0.13^{a}$ \\
\hline $52-104$ & 40 & $42.03 \pm 0.37 \mathrm{ab}$ & $24.22 \pm 0.15^{b}$ & $46.89 \pm 0.63^{b}$ & $18.66 \pm 0.38^{b}$ & $10.86 \pm 0.16$ & $7.83 \pm 0.12^{b}$ \\
\hline $104+$ & 30 & $42.69 \pm 0.32^{b}$ & $24.27 \pm 0.17 b$ & $47.20 \pm 0.65^{b}$ & $21.35 \pm 0.32^{c}$ & $10.37 \pm 0.18$ & $7.58 \pm 0.14^{b}$ \\
\hline Ortalama & & $42.02 \pm 0.20$ & $24.02 \pm 0.09$ & $44.31 \pm 0.39$ & $19.03 \pm 0.20$ & $10.55 \pm 0.10$ & $7.49 \pm 0.08$ \\
\hline Tavuk & & $*$ & - & $* * *$ & $* * *$ & $*$ & - \\
\hline $20-52$ & 66 & $39.04 \pm 0.30^{\mathrm{a}}$ & $22.89 \pm 0.13$ & $23.16 \pm 0.44^{a}$ & $8.73 \pm 0.21^{\mathrm{a}}$ & $9.02 \pm 0.15^{\mathrm{a}}$ & $6.65 \pm 0.10$ \\
\hline $52-104$ & 40 & $40.14 \pm 0.40^{b}$ & $22.88 \pm 0.18$ & $28.49 \pm 0.57 \mathrm{~b}$ & $9.77 \pm 0.29 b$ & $9.19 \pm 0.19 \mathrm{ab}$ & $6.89 \pm 0.12$ \\
\hline $104+$ & 40 & $40.37 \pm 0.40^{b}$ & $22.45 \pm 0.18$ & $30.03 \pm 0.57 c$ & $10.75 \pm 0.29 c$ & $9.64 \pm 0.19 \mathrm{~b}$ & $6.90 \pm 0.12$ \\
\hline Ortalama & & $38.86 \pm 0.21$ & $22.74 \pm 0.09$ & $27.23 \pm 0.31$ & $9.75 \pm 0.16$ & $9.29 \pm 0.10$ & $6.82 \pm 0.07$ \\
\hline $\begin{array}{c}\text { Yaş } \\
\text { Dönemi } \\
\text { (hafta) }\end{array}$ & $\mathrm{N}$ & $\begin{array}{l}\text { Gaga Uzunluğu } \\
(\mathrm{mm})\end{array}$ & $\begin{array}{c}\text { Gaga } \\
\text { Genişliği } \\
(\mathrm{mm})\end{array}$ & $\begin{array}{c}\text { Kulak Lobu } \\
\text { Uzunluğu } \\
\text { (mm) }\end{array}$ & $\begin{array}{c}\text { Kulak Lobu } \\
\text { Genişliği } \\
\text { (mm) }\end{array}$ & $\begin{array}{c}\text { Sakal } \\
\text { Uzunluğu } \\
(\mathrm{mm})\end{array}$ & $\begin{array}{l}\text { Sakal Genişliği } \\
(\mathrm{mm})\end{array}$ \\
\hline Horoz & & $*$ & $* * *$ & $*$ & - & $*$ & $* *$ \\
\hline $20-52$ & 35 & $17.18 \pm 0.17^{\mathrm{a}}$ & $9.87 \pm 0.09^{a}$ & $15.00 \pm 0.21^{\mathrm{a}}$ & $12.85 \pm 0.14$ & $15.21 \pm 0.21^{\mathrm{a}}$ & $11.78 \pm 0.17^{\mathrm{a}}$ \\
\hline $52-104$ & 40 & $17.36 \pm 0.17 \mathrm{ab}$ & $10.49 \pm 0.09 b$ & $15.97 \pm 0.20^{\mathrm{b}}$ & $13.03 \pm 0.13$ & $15.12 \pm 0.20^{a}$ & $11.73 \pm 0.16^{\mathrm{a}}$ \\
\hline $104+$ & 30 & $17.71 \pm 0.15^{b}$ & $10.67 \pm 0.11^{b}$ & $15.27 \pm 0.23^{a}$ & $13.00 \pm 0.15$ & $15.89 \pm 0.23^{b}$ & $11.03 \pm 0.19 b$ \\
\hline Ortalama & & $17.42 \pm 0.09$ & $10.34 \pm 0.06$ & $15.41 \pm 0.12$ & $12.96 \pm 0.08$ & $15.41 \pm 0.12$ & $11.51 \pm 0.10$ \\
\hline Tavuk & & - & - & $*$ & - & $* *$ & $*$ \\
\hline $20-52$ & 66 & $16.91 \pm 0.16$ & $9.98 \pm 0.08$ & $12.11 \pm 0.13^{a}$ & $10.37 \pm 0.11$ & $11.08 \pm 0.18^{a}$ & $7.01 \pm 0.16^{\mathrm{a}}$ \\
\hline $52-104$ & 40 & $16.66 \pm 0.21$ & $10.03 \pm 0.10$ & $12.53 \pm 0.17 \mathrm{ab}$ & $10.38 \pm 0.15$ & $11.76 \pm 0.22^{b}$ & $7.40 \pm 0.20^{\mathrm{ab}}$ \\
\hline $104+$ & 40 & $16.91 \pm 0.21$ & $10.17 \pm 0.10$ & $12.87 \pm 0.17 \mathrm{~b}$ & $10.49 \pm 0.15$ & $12.13 \pm 0.22^{b}$ & $7.57 \pm 0.20^{\mathrm{b}}$ \\
\hline Ortalama & & $16.83 \pm 0.11$ & $10.06 \pm 0.06$ & $12.50 \pm 0.09$ & $10.41 \pm 0.08$ & $11.66 \pm 0.12$ & $7.33 \pm 0.11$ \\
\hline
\end{tabular}

***: $\mathrm{P}<0.001$; **: $\mathrm{P}<0.01$; $: \mathrm{P}<0.05$; -: $\mathrm{P}>0.05$. Her bir cinsiyet için aynı sütunda farklı harfler tașıyan ortalamalar arasındaki fark önemli bulunmuștur. - : Önemsiz

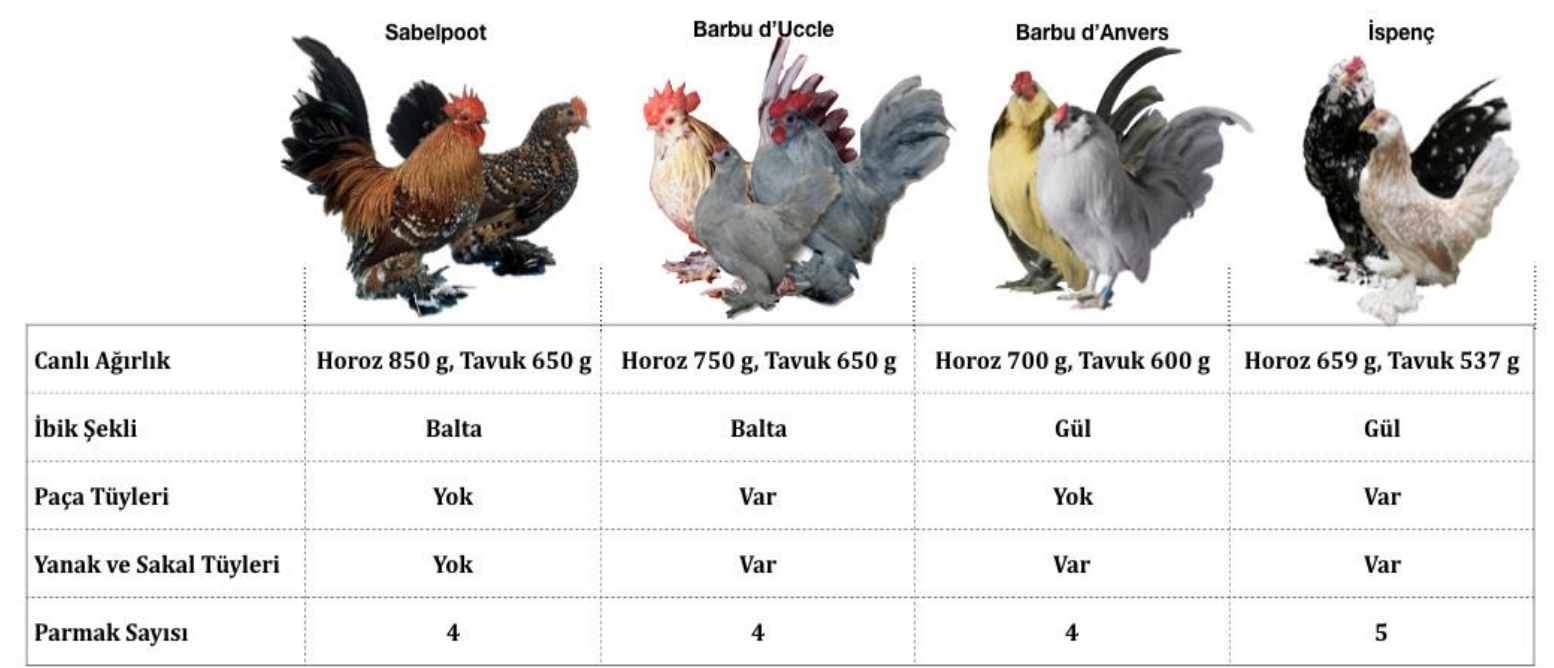

Şekil 3. İspenç genotipinin Hollanda Bantam, Barbu d’Uccle ve Barbu d'Anvers minyatür ırkları ile karşılaștırılması [13].

Ülkemizde çok uzun yıllardır yetiştiriciliği yapılan İspenç genotipi sahip olduğu canlı ağırlık sınırları sebebiyle minyatür tavuk irkları kategorisinde yer almaktadır. EE tarafindan 2016 yılında yayınlanan minyatür tavuk ırkı standartları raporunda dünya genelinde 151 adet minyatür tavuk irkı tanımlanmış [9] ve bu tavuk irkları arasında Hollanda'da yetiştirilen Sabelpoot (Dutch Bantam) ve Belçika'da yetiştirilen Barbu d'Anvers ve Barbu d'Uccle irkları, İspenç genotipi ile fenotipik benzerlikler göstermektedir. Ancak vücut canlı ağırlı̆̆l bakımından birbirine benzer ağırlıkta olan bu irklar, ibik şekli, ayak bileği etrafındaki tüylenme, parmak sayısı ve vücut durușu bakımından birbirlerinden ayrılmaktadır (Şekil 3). İspenç genotipi ayak bileğini kaplayan paça tüyleri görünümü itibariyle Sabelpoot ve Barbu d'Uccle (Sabelpoot x Barbu d'Anvers) ırklarına benzerlik göstermektedir. Ancak her iki ırkın da vücut yapısı, vücut duruşu ve ibik şekilleri İspenç genotipinden farklık göstermektedir. İspenç genotipi her ne kadar sahip olduğu gül ibik șekli ile Barbu d'Anvers ırkına benzerlik gösterse de İspenç genotipinde gül ibik yapısı şekil ve papilla sıraları itibariyle Barbu d'Anvers ırkından farklılık göstermektedir. Barbu d'Anvers ırkındaki gül ibik şekli kafatası üzerinden oksipital kemiğe doğru basık bir kuyruk biçiminde uzanırken, İspenç genotipinde 
gül ibik şekli yoğun papillalı, geniş taç şeklinde ve daha yuvarlak bir biçimdedir. Bu durum İspenç genotipinin ibik şekli bakımından farklı bir allelik yapıya sahip olduğunu ifade etmektedir.

Minyatür tavuk ırklarında düşük vücut ağırlığı ve minyatür vücut tipinin otozomal ve cinsiyete bağlı kalıtım gösteren cücelik genleri $\left(\mathrm{adw}, \mathrm{dw}, \mathrm{dw}^{\mathrm{B}}\right)$ etkisi ile gerçekleştiği bilinmektedir $[14,15,16]$. İspenç tavuk ve horozlarında canlı ağırlık ve morfolojik yapı incelendiğinde İspenç fenotipinde de cücelik genlerinin etkileri görülmektedir. Araştırma bulgularına göre İspenç tavuk ve horozlarında ergin canlı ağırlık ortalamaları sırasıyla 537 ve 659 g olarak saptanırken, hafif ve orta ağır kategorisinde tescil edilmiş yerli tavuk ırklarımızdan Gerze tavuk ve horozlarında ergin canlı ağırlık sırasıyla 1100 ve 1850 g olarak, Denizli irkı tavuk ve horozlarında ergin canlı ağırlık sırasıyla 1100 ve 2050 g olarak bildirilmiştir [17]. İspenç genotipinde, canlı ağırlık ortalamalarında olduğu gibi diğer morfolojik ölçümlerde de cücelik genleri etkileri görülmektedir. İspenç tavuk ve horozlarında 20-52 haftalık yaş dönemine ait incik uzunluğu sırasıyla $56.42 \mathrm{~mm}$ ve $59.64 \mathrm{~mm}$ olarak saptanirken, Raut vd. [18] 20 haftalık yaştaki cüce tavuk ve horozların incik uzunluğunu sirasıyla $51 \mathrm{~mm}$ ve $60 \mathrm{~mm}$ olarak bildirmiştir. Cozzi vd.'nin [19] İtalyan minyatür tavuk ırkı Mericanel della Brianza üzerinde yaptıkları morfolojik ölçümlerde horoz ve tavuklara ait incik uzunluğu (sırasıyla $5.45 \mathrm{~cm}$ ve $5.12 \mathrm{~cm}$ ) ve incik çapı

Tablo 5. İspenç horoz ve tavuklarının ayak ve bacak bölgesi morfolojik ölçümleri.

\begin{tabular}{|c|c|c|c|c|c|}
\hline $\begin{array}{l}\text { Yaş Dönemi } \\
\text { (hafta) }\end{array}$ & $\mathrm{N}$ & $\begin{array}{l}\text { Parmak Sayısı } \\
\text { (adet) }\end{array}$ & $\begin{array}{c}\text { Orta parmak } \\
\text { Uzunluğu } \\
(\mathrm{mm})\end{array}$ & $\begin{array}{l}\text { İncik Uzunluğu } \\
(\mathrm{mm})\end{array}$ & $\begin{array}{l}\text { İncik Çap } 1 \\
(\mathrm{~mm})\end{array}$ \\
\hline Horoz & & & - & - & $* * *$ \\
\hline $20-52$ & 35 & 5 & $40.11 \pm 0.22$ & $59.64 \pm 0.26$ & $9.95 \pm 0.11^{\mathrm{a}}$ \\
\hline $52-104$ & 40 & 5 & $40.64 \pm 0.20$ & $59.46 \pm 0.27$ & $10.86 \pm 0.10^{b}$ \\
\hline $104+$ & 30 & 5 & $40.07 \pm 0.24$ & $59.78 \pm 0.28$ & $11.07 \pm 0.12^{b}$ \\
\hline Ortalama & & & $40.27 \pm 0.13$ & $60.09 \pm 0.15$ & $10.62 \pm 0.06$ \\
\hline Tavuk & & & $*$ & - & - \\
\hline $20-52$ & 66 & 5 & $37.07 \pm 0.18^{a}$ & $56.42 \pm 0.30$ & $9.11 \pm 0.09$ \\
\hline $52-104$ & 40 & 5 & $37.59 \pm 0.23^{a b}$ & $56.60 \pm 0.38$ & $9.25 \pm 0.11$ \\
\hline $104+$ & 40 & 5 & $37.99 \pm 0.23^{b}$ & $56.78 \pm 0.38$ & $9.36 \pm 0.11$ \\
\hline Ortalama & & & $37.55 \pm 0.12$ & $56.60 \pm 0.21$ & $9.24 \pm 0.06$ \\
\hline
\end{tabular}

(sırasıyla $6.3 \mathrm{~mm}$ ve $4.7 \mathrm{~mm}$ ) özelliklerine ait ortalamalar İspenç horoz ve tavukları için saptanan değerlerden daha düşük bulunmuştur. Minyatür tavuk ırklarında yapılan araştırmalarda ırktan ırka farklılık göstermekle birlikte horoz ve tavuklarda incik uzunluğunun 18 haftalık yaşa kadar doğrusal olarak arttığı ve 46 haftalık yaşa kadar sabit kaldığı bildirilmiştir [20]. Bu sonuçlara benzer bir biçimde İspenç horoz ve tavuklarında incik uzunluğu değerlerinin yaş dönemine göre değişimi önemli bulunmamıştır.

Tavuklar genel olarak her ayakta dört adet parmağa sahiptirler fakat Silkie, Beijing-You, Dorking, Fizan ve Sultan gibi tavuk ırkları ekstra ayak parmaklarına sahiptirler [21]. Tavuklarda, insanlarda, farelerde ve diğer omurgalılarda çoklu parmak oluşumuna neden olan ve yüksek düzeyde kalıtsal olan bu "çok parmaklılık" (polydactyly) durumuna Po geninin neden olduğu saptanmıştır [22, 23]. Otozomal dominant karakterdeki Po (polydactyly) geninin etkisi İspenç tavuk ve horozlarında da görülmekte ve bu gen etkisiyle İspenç genotipinde her ayakta beş adet parmak oluşumu izlenmektedir. Minyatür tavuk ırkları arasında rastlanmayan beş parmak özelliğinin İspenç genotipinde bulunması, İspenç genotipinin diğer minyatür ırklardan en önemli genetik farklılığı olarak gösterilebilir.

\section{Sonuç}

Sonuç olarak İspenç tavuk ve horozlarında bazı morfolojik özellikleri incelemek amacıyla yapılan bu araştırma, İspenç genotipi üzerine yapılan ilk bilimsel araştırma niteliğini taşımaktadır. Özellikle sahip olduğu vücut ölçülerine göre İspenç genotipi Avrupa'da en küçük minyatür ırklar için kullanılan tam Bantam (tam cüce) kategorisi içerisinde yer alabilecek olan İspenç tavuk ve horozları için saptanan morfolojik standartların ve fenotipik gözlemlerin moleküler genetik yöntemler kullanılarak desteklenmesi, İspenç genotipinin genetik karakterizasyonun yapılması ve benzer minyatür tavuk ırklarıyla genetik akrabalıklarının araştırılması İspenç genotipiyle ilgili daha detaylı bilgiye sahip olunmasına olanak sağlayacaktır.

\section{Teşekkür}

Araștırmanın yürütülmesinde ve örnekleme sırasında yardımları ve desteklerinden ötürü başta Aleksandra Rywacka olmak üzere İspenç Clup ve Türkiye İspenç Kulübü üyelerine ve Türkiye Süs Tavukları ve Bahçe Hayvanları Federasyonu'na teşekkürlerimi sunarım. 


\section{Kaynakça}

[1] FAO 2015. The Second Report on the State of the World's Animal Genetic Resources for Food and Agriculture, edited by B.D. Scherf \& D. Pilling. FAO Commission on Genetic Resources for Food and Agriculture Assessments. Rome http://www.fao.org/3/a-i4787e.pdf (Erişim Tarihi: 31 Temmuz 2018).

[2] FAO (Food and Agriculture Organization). 2007. The State of the World's Animal Genetic Resources for Food and Agriculture. Edi: Barbara Rischkowsky \& Dafydd Pilling. Rome. Italy.

[3] Özdemir, D., Özdemir, E. D., Marchi, M. D., \& Cassandro, M. 2013. Conservation of local Turkish and Italian chicken breeds: a case study. Italian Journal of Animal Science, 12(2), e49.

[4] Ebegbulem V.N., Ita U.R. 2016. Conservation of Genetic Diversity: It's Relevance in Poultry Production, Animal molecular Breeding, 6(3):15.

[5] Özdemir D., Aksoy T. 2015. Yerli tavuk irkları. Dünya Dört Mevsim Dergisi, 13:44-48.

[6] Anonim, 2016. İspenç ırk özellikleri, İnternet forum sitesi, http://www.evcilsevgisi.com, (Erişim Tarihi: 31 Temmuz 2018)

[7] İnalcık H. 1959. Osmanlılarda Raiyyet Rüsumu, Belleten, 23(92): 575- 610.

[8] Yılmaz, O. 2012. Güvercin (Columba Livia) yetiştiriciliği. Veni Vidi Vici Yayınları, Ankara, $218 \mathrm{~s}$.

[9] EE, 2016. EListing of Bantam breeds, European Association of Poultry, Pigeon, Cage Bird, Rabbit and Cavy Breeders, Technical notes, http://www.ententeee.com/sections/poultry/technical/ (Erişim Tarihi: 31 Temmuz 2018)

[10] FAO, 2012. Phenotypic characterization of animal genetic resources. FAO Animal Production and Health Guidelines No.11. Rome. http://www.fao.org/docrep/015/i2686e/i2686 e00.pdf (Erişim Tarihi: 31 Temmuz 2018)

[11] Francesch, A., Villalba, I., Cartañà, M. 2011. Methodology for morphological characterization of chicken and its application to compare Penedesenca and Empordanesa breeds, Animal Genetic Resources, 48:79-84.

[12] IBM Corp. Released 2015. IBM SPSS Statistics for Windows, Version 23.0. Armonk, NY: IBM Corp.
[13] EE, 2006. Rassegeflügel-Standard für Europa in Fabre. Hühner und Zwerghühner, Nünberg, 800s.

[14] Cole, R.K. 2000. An autosomal dwarfism in the domestic fowl, Poultry Science, 79(11), 15071516.

[15] Chen, C.F., Chen, Y.H., Tixier-Boichard, M., Cheng, P.Y., Chang, C.S., Tang, P.C., Lee, Y.P. 2009. Effects of the chicken sex-linked dwarf gene on growth and muscle development, Asian-Australasian Journal of Animal Sciences, 22(7), 937-942.

[16] Wang, W.T., Cao, J., Xu, L.X., Chen, B. 2018. A systemic analysis on dwarf gene of Xingyi bantam, Indian Journal of Animal Research, 52(2), 179-185.

[17] TAGEM, 2009. Türkiye Evcil Hayvan Genetik Kaynakları Tanıtım Kataloğu. Ankara. Erişim: https://www.tarim.gov.tr/TAGEM/Belgeler/yay in/Katalog\%20Türkçe.pdf (Erişim Tarihi: 31 Temmuz 2018)

[18] Raut, S.N., Khan, A.G., Nema, R.P., Bhardwaj, J.K. 1996. Influence of sex on shank length and association of shank length with economic traits, in color dwarf Krishna-J layer, Proceedings of 20th world`s poultry Congress September 2-5, 1996. New Delhi, India, Vol. IV p.33.

[19] Cozzi, M.C., Colombo, E., Zaniboni, L., Madeddu, M., Mosca, F., Strillacci, Longeri, M., Bagnato, A., Cerolini, S. 2017. Phenotypic and genetic characterization of the Italian bantam chicken breed Mericanel della Brianza, Livestock Science, 205, 56-63.

[20] Yeasmin, T., Howlider, M.A.R. 2013. Effects of autosomal dwarf gene on growth and shank length of chicken, Bangladesh Veterinarian, 30(1), 25-32.

[21] Zhang, Z., Nie, C., Jia, Y., Jiang, R., Xia, H., Lv, X., Chen, Y., Li, J., Li, X., Ning, Z., Xu, G., Chen, J., Yang, N., Qu, L. 2016. Parallel Evolution of Polydactyly Traits in Chinese and European Chickens. PLoS ONE 11(2): e0149010.

[22] Clark, R.M, Marker, P.C., Kingsley, D.M. 2000. A novel candidate gene for mouse and human preaxial polydactyly with altered expression in limbs of Hemimelic extra-toes mutant mice, Genomics, 67(1): 19-27.

[23] He, C., Chen, Y., Yang, K., Zhai, Z., Zhao, W., Liu, S., Ding, J., Dai, R., Yang, L., Xu, K., Zhou, Z., Gu, C., Huang, Q., Meng, H. 2017. Genetic pattern and gene localization of polydactyly in Beijing fatty chicken, PLoS ONE, 12(5), e0176113. 